\title{
口腔癌における術前化学療法と栄䓹学的予後指数
}

\author{
野口誠・仲盛健治・関口隆 \\ 平塚博義・小浜源郁

\section{Clinical analysis of prognostic nutritional index in induction chemotherapy for oral cancer}

\author{
Makoto Noguchi • Kenji Nakamori • Takashi Sekiguchi \\ Hiroyoshi Hiratsuka • Gen-iku Kohama
}

\begin{abstract}
Thirty-eight previously untreated patients with carcinoma of the oral cavity were analyzed in regard to the relationship between induction chemotherapy, primarily employing CDDP, and nutritional status. The prognostic nutritional index (PNI) proposed by Onodera was used to quantify nutritional status. The PNI value was calculated by the following formula: PNI $=10 \times$ serum albumin value $+0.005 \times$ lymphocyte count. The PNI value before chemotherapy was $47.2 \pm 6.7$ in patients showing a sufficient response to chemotherapy and 48. $1 \pm 4.9$ in nonresponders. These results were comparable. Regarding the change in PNI after chemotherapy, a rise in PNI was more frequently noted in responders than in nonresponders $(52.9 \%$ vs. $9.5 \%, \mathrm{P}<0.05)$. These results were attributed to the reduction in pain associated with mastication or swallowing in patients showing tumor regression in response to anticancer therapy, resulting in increased appetite in this group.
\end{abstract}

Key words: prognostic nutritional index (栄養学的予後指数), induction chemotherapy (術前 化学㙩法), oral cancer (口腔癌)

\section{緒言}

近年の臨床栄養学の進歩のなかで, 宿主の免疫能が栄 養状態と密接に関連していることがあきらかとなってき た ${ }^{1,2)}$.このよらなことから，癌患者の治療にあたって， 栄養状態を把握しておくことは各種抗癌療法の効果の子 測ひいては予後を予測するらえで, 重要と考えられてい る.

われわれの教室では術前化学療法十外科療法の治療シ ステムによってロ腔癌の治療を行っている。このよら な, 後続療法として外科療法を予定する術前化学療法で は，それによって患者の栄養状態または免疫能を低下さ せることなく抗腫瘍効果を得ることは外科療法後の合併 症や術創の治癒不全を䂆防するらえで重要と考えられ，

札幌医科大学口腔外科学講座

（主任：小浜源郁教授）

Department of Oral Surgery, Sapporo Medical

College (Chief: Prof. Gen-iku, Kohama)

受付日: 平成 5 年 1 月 18 日
さらには遠隔成績の向上に資するものと思われる。しか し, 現在までのところ口腔癌患者に拈ける栄養状態と化 学療法効果との関連について検討した報告はみられな い.

一方, 栄養状態の指標として小野寺は血清アルブミン 值および末梢血リンパ球数より算出する栄養学的予後指 数 (Prognostic Nutritional Index, 以下 PNI) を提唱 し，これが癌患者の手術の適応決定および予後の判定に 有用であることを報告している ${ }^{3,4)}$.

そこで, 本研究では CDDPを中心とした術前化学療法 を行った口腔癌一次症例を対象に, 化学療法効果と栄養 状態との関連について小野寺によって提唱された PNI を指標として検討したので報告する。

\section{対象症例および治療法}

対象症例は当科で術前化学療法の後に外科療法を施行 した口腔癌一次症例38例である。性別内訳は男性32例， 女性 6 例で, 年齢は31〜81歳, 平均57.8歳である. 原発 部位は舌 : 14例, 歯肉： 7 例, 口底：9例, 口峡咽頭： 
表 1 対象症例の背景因子と治療前 PNI

\begin{tabular}{|c|c|c|c|}
\hline \multicolumn{2}{|c|}{ 背景因子 } & 例 数 & PNI 值 \\
\hline \multicolumn{2}{|c|}{ 全 例 } & 38 & $47.7 \pm 5.7$ \\
\hline \multirow{2}{*}{ 性 } & 男 & 32 & $47.8 \pm 5.2$ \\
\hline & 女 & 6 & $47.5 \pm 8.5$ \\
\hline \multirow{2}{*}{ 年 } & 59歳以下 & 19 & $48.5 \pm 5.0$ \\
\hline & 60 歳以上 & 19 & $46.9 \pm 6.4$ \\
\hline \multirow{4}{*}{ 臨床病期 } & I & 7 & 49. $9 \pm 6.1$ \\
\hline & II & 14 & $46.5 \pm 4.7$ \\
\hline & III & 5 & $47.6 \pm 3.5$ \\
\hline & IV & 12 & $47.8 \pm 7.3$ \\
\hline
\end{tabular}

$\mathrm{t}$ 検定 : N.S.

4 例, 煩粘膜： 3 例, 下唇： 1 例である. 臨床病期分類 (1987年, UICC) は stage I $: 7$ 例, stage II $: 14$ 例, stage III： 5 例, stage IV $: 12$ 例である。経管栄養ないし 中心静脈栄養による栄養療法を行った症例は含まれてい ない.

化学療法のレジメンはシスプラチシ (CDDP) $80 \mathrm{mg} /$ body を先行投与し，つづいてブレオマイシン (BLM) (5 mg/time, 総量 $45 \sim 60 \mathrm{mg} / \mathrm{body})$ まはペプロマイシ ソ (PEP) $(2.5 \mathrm{mg} / \mathrm{time}$, 総量 $50 \mathrm{mg} /$ body) と免疫療 法剤である OK-432 (任意量)を隔日投与するものであ る. 以上を 1 クールとして, 化学療法効果, 患者の全身 状態を総合評価したうえで，1クールないし2クールを 施行したが，両施行例とも19例である.

\section{研 究 方 法}

化学療法効果の判定は, 化学療法前後に和ける腫瘍長 径とそれに直角に交わる最大径の積を求め，これにより 縮小率を算出し $50 \%$ 以上を有効， $50 \%$ 未満を無効例とし た.

PNI は小野寺の報告に基づき次式により，化学療法 前後の值を求めた。

$\mathrm{PNI}=$ 末梢血リンパ球数 $+10 \times$ 血清アルブミン值 $(\mathrm{mg} / \mathrm{d} l)$

PNI の值に 2.0 以上の違いがあった場合を变動ありと して評価した．末梢血リンパ球数扣よび血清アルブミン 值の変動が予想される局所の炎症症状の強い症例, 脱水 状態にある症例などは対象外とした。

\section{結果}

化学療法効果 : 有効率は全症例で, $44.7 \%(17 / 38)$, 1 クール施行例では $36.8 \%(7 / 19), 2$ クール施行例で
表 2 化学療法奻果と治療前 PNI

\begin{tabular}{|c|c|c|}
\hline & 化学療法奻果 & PNI 值 \\
\hline \multirow{2}{*}{$\frac{\text { 全 }}{(\mathrm{n}=38)}$} & 有奻 $(n=17)$ & $47.2 \pm 6.7$ \\
\hline & 無奻 $(n=21)$ & $48.1 \pm 4.9$ \\
\hline \multirow{2}{*}{$\begin{array}{l}1 \text { クール } \\
(n=19)\end{array}$} & 有効 $(n=7)$ & $49.2 \pm 8.3$ \\
\hline & 無効 $(n=12)$ & $48.4 \pm 4.1$ \\
\hline \multirow{2}{*}{$\begin{array}{l}2 \text { クール } \\
(n=19)\end{array}$} & 有効 $(n=10)$ & $45.8 \pm 5.3$ \\
\hline & 無効 $(n=9)$ & $47.8 \pm 6.1$ \\
\hline
\end{tabular}

$\mathrm{t}$ 㭘定 : N.S.

は52.6\% (10/19) であった.

治療前 PNI : 全症例の PNI は47.7 5 5.7であった。 男女別にみた PNI は男性（32例）47.8 5 5.2, 女性( 6 例） $47.5 \pm 8.5$ であった。年齢を便宜的に 59 歳以下と 60 歳以上に分けると, 59 歳以下 (19例) 48.5 5 5. 0, 60 歳 以上（19例） $46.9 \pm 6.4$ であり，59歳以下の症例でやや 高い傾向がみられたが, 推計学的有為差はみられなかっ た。臨床病期別にみると, stage I （7 例） 49.9土6.1, stage II (14例) $46.5 \pm 4.7$, stage III ( 5 例) $47.2 \pm 3.4$, stage IV (12例) 47.8土7.3であった（表 1 ).

化学療法効果と治療前 PNI : 化学療法有効例 (17例) の平均 PNI は47.2土6.7, 無効例 (21例) では $48.1 \pm$

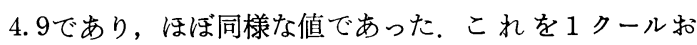
よび 2 クール施行例に分けてみると， 1 クール施行，有 效例 (7 例) では49.2 8.3 , 無效例 (12例) では 48.4 $\pm 4.1,2$ クール施行, 有効例 (10例) では45.8土5.3, 無効例（9例）では47.8土6.1 であったが，いずれも推 計学的有為差はみられなかった（表 2).

化学療法効果と PNI の推移 : 化学療法効果と PNI の 推移との関連をみると, 有効例では上昇；9/17例（52.9 \%), 変化なし； $2 / 17$ 例 $(11.8 \%)$, 下降；6/17(35.3\%) で無效例では上昇； $2 / 21(9.5 \%)$ ，変化なし； 7/21例 (33.3\%), 下降；13/21 例 (61.9\%) であり，化学療法 有効例では PNI 上昇例が，無効例では下降例が多くみ られた $(\mathrm{P}<0.05)$. また，このなかで1クール施行例 では有効例で上昇； $2 / 7$ 例 $(28.6 \%)$, 変化なし； $1 / 7$ 例 (14. 3\%), 下降； $4 / 7(57.1 \%)$, 無効例で，上昇；0/12 例，変化なし； $3 / 12$ 例 $(25.0 \%)$, 下降; 9/12例 $(75.0$ \%) であった $(\mathrm{P}>0.05) .2$ クール施行例では有効例 で，上昇； $7 / 10$ 例 $(70.0 \%)$, 变化なし； $1 / 10$ 例 $(10.0$ $\%)$, 下降; $2 / 10$ 例 $(20.0 \%)$, 無効例では上昇, $2 / 9$ 例 $(22.2 \%)$, 変化なし; $3 / 9$ 例 $(33.3 \%)$, 下降； $4 / 9$ 例 (44. $4 \%$ ) であり，有効例では上昇例が，無効例では下 降例が多くみられる傾向があったが，推計学的有為差は 認められなかった（表了）。 
表 3 化学療法奻果と PNI の変動

\begin{tabular}{|c|c|c|c|c|}
\hline & \multirow{2}{*}{ 化学療法奻果 } & \multicolumn{3}{|c|}{ PNI の変動 } \\
\hline & & 上昇 & 変動なし & 下降(\%) \\
\hline \multirow{2}{*}{ 全 例 } & 有効 $(n=17)$ & $9 / 17(52.9)$ & $2 / 17(11.8)$ & $6 / 17(35.3)$ \\
\hline & 無効 $(n=21)$ & $2 / 21(9.5)$ & $7 / 21(33.3)$ & $13 / 21(61.9)$ \\
\hline \multirow{2}{*}{$1 ク ー ル$} & 有効 $(n=7)$ & $2 / 7(28.6)$ & $1 / 7(14.3)$ & $4 / 7(57.1)$ \\
\hline & 無効 $(n=12)$ & $0 / 12(0.0)$ & $3 / 12(25.0)$ & $9 / 12(75.0)$ \\
\hline \multirow{2}{*}{2 クール } & 有効 $(n=10)$ & $7 / 10(70.0)$ & $1 / 10(10.0)$ & $2 / 10(20.0)$ \\
\hline & 無効 $(n=9)$ & $2 / 9(22.2)$ & $3 / 9(33.3)$ & $4 / 9(44.4)$ \\
\hline
\end{tabular}

$* \chi^{2}$ 㭘定 $: \mathrm{P}<0.05, * * \chi^{2}$ 㭘定 $:$ N.S.

表 42 クール施行例の化学療法効果と 1 クール終 了時での PNI の変動

$\left.\begin{array}{l|c|c|c}\hline \multirow{2}{*}{\begin{array}{c}\text { 化学療法 } \\ \text { 効果 }\end{array}} & \multicolumn{3}{|c}{\text { PNI の変動 }} \\ \hline \text { 上 昇 } & \text { 変動なし } & \text { 下降(\%) } \\ \hline \begin{array}{l}\text { 有 効 } \\ (\mathrm{n}=10)\end{array} & 6 / 10(60.0) & 3 / 10(30.0) & 1 / 10(10.0) \\ \hdashline \begin{array}{l}\text { 無 効 } \\ (\mathrm{n}=9)\end{array} & 0 / 9(0.0) & 3 / 9(33.3) & 6 / 9(66.7)\end{array}\right) *$

$* \chi^{2}$ 検定 $: \mathrm{P}<0.01$

\section{2 クール施行例の化学療法効果とその 1 クール終了時} の PNI の変動：化学療法 2 クール施行例の 1 クール終 了時での PNI の変動を効果別にみると, 有効例(10例)で は上昇；6/10例 $(60.0 \%)$, 変動なし；3/10例(10.0\%), 下降；1/10例 $(10.0 \%$ )，無効例（9例）では上昇；0/9 例 $(0 \%)$, 変動なし; 3/9例 $(33.3 \%)$, 下降; $6 / 9$ 例 $(66.7 \%)$ であり, 有効例では上昇, 無効例では下降す る症例が多くみられた（P<0.01，表 4$)$.

\section{考察}

担癌生体の免疫能の低下がいかなる機序で起こるかに ついては，いまだ明確な解答は得られていない.しか し, Smythe $5^{5)}$, Law ら ${ }^{6)}$ の報告にみられるように, 栄養状態の悪化が担癌生体の免疫能低下の重要な要因で あることは疑いのないことのようである.

一方，1969年に開発された抗癌剤 CDDP は各種癌に 対して高い抗腫瘍効果を有して括り, 頭頸部癌の化学療 法においてもその主体を成してきている。しかし，副作 用としての悪心, 嘔吐, 食欲不振といった消化器症状は ほぼ必発といえ，その程度によって後続療法を行らうえ で障害となることも予想される。われわれの施設におい
ても口腔癌の術前療法として CDDP を中心とした化学 療法を施行しているが，今回の検討症例のなかには前述 した副作用により外科療法を行いえなかった症例はみら れなかった。 しかしながら，小野寺による栄養学的予後 指数 (PNI) を栄養状態の指標とすると, 化学療法を行 らことにより值の上昇する症例や下降する症例がみら れ, これらの変動と化学療法効果の関連について検討し たところ若干の知見を得たので以下に考察を加えた.

他領域に和ける小野寺による PNI を用いた検討は中 井ら7)による肺癌の報告をみるのみであるが，これによ ると肺癌患者の治療前 PNI 值は平均 $48.2 \pm 6.8$ と報告 されている，われわれの口腔癌患者の治療前 PNI 值は 平均 $47.7 \pm 5.7$ であり中井らの結果と近似の值であった. 一般に, 胃癌や食道癌といった消化器癌では経口摂取障 害による栄養障害が起こりやすく，乳癌や肺癌などでは 消化器癌に比して栄養障害は起こりにくいと考えられて いる1). 口腔は消化管の入り口でありこの部の機能障害 は, 経口摂取障害と直接的に関わることは容易に想像で きる、今回のわれわれの結果は, 高度進展癌で栄養障害 の顕著な症例は術前化学療法十外科療法の治療システム が適応されず，検討対象から除外されたことが反映され た結果と思われた。

治療前の栄養状態と化学療法効果に関しては，免疫能 を含めた栄養状態の良好な症例の方がより化学療法の奏 効率が高いという報告がみられる7,8).われわれの結果 では治療前の PNI と化学療法効果との間にあきらかな 関連はみられず，上述の報告を支持する結果は得られな

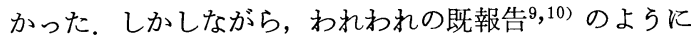
治療前の生検組織における $\mathrm{T}$ 細胞浸潤を局所の免疫能の 指標とすると，あきらかに免疫能の高い症例に化学療法 の有効例が多くみられ，このことを勘案すると PNI が 局所の免疫能まで反映するものではないことが示唆され た。

一方, 化学療法前後の PNI の変動をみると, 化学療 
法有効例で PNI の上昇例が多いことがあきらかとなっ た。このことは化学療法による抗腫瘍効果の発現に伴い 食物摂取時の接触痛あるいは嚥下運動時の癌性疼痛が緩 和されたことにより食物摂取量が増加したことに起因す ると考兄られた。ささらに, 化学療法 2 クール施行例の 1 クール終了時までの PNI の変動をみると, 全 2 クール 終了時での化学療法有効例で PNI の上昇している症例 が多くみられ，PNI の変動が化学療法を 2 クールまで 施行するか否かを決定するら皇での参考所見となること が示唆された。 以上の結果は PNI の上昇は化学療法の 効果発現に伴う2 次的な変動と考えられたが，化学療法 を行う際に IVH などによる積極的栄養療法を併用する ことによって化学療法の効果を高めることが可能かどら かという疑問が生じる. Valdivieso ら ${ }^{11)}$ は肺小細胞癌 症例に対する化学療法で，IVH を併用した群とそうで ない群とを比較検討した結果，IVH の併用により化学 療法効果の改善はみられなかったものの，治療による患 者の体重減少の予防には有用であったと報告している. また，平山ら ${ }^{122}$ は放射線，化学療法と併用して IVH を 行うことにより, 食欲不振, 咽頭痛などの副作用を軽減 し予定された治療計画を無理なく完遂できるようになる と述べている。 このように, 各種抗癌療法に積極的栄養 療法を併用することにより直接的に治療効果を高めるこ とには疑問が残るが, 副作用が軽減され, 後続療法が行 いやすくなるのみではなく，栄養不良による免疫能の低 下が予防されひいては遠隔成績の向上に結びつく可能性 が考壳られた。

\section{ま と め}

CDDPを中心とした術前化学療法を行った口腔癌一 次症例を対象に, 化学療法効果と栄養状態との関連につ いて小野寺によって提唱された PNIを用いて検討を行 い以下の結果を得た。

1. 化学療法効果別の治療前 PNI は, 有効例 $47.2 \pm$ 6.7, 無効例 $48.1 \pm 4.9$ とほぼ同様な值であった。

2. 化学療法効果別に PNI の変動をみると, 有効例で は上昇 (9/17例, $52.9 \%$ ), 無効例では下降 (13/21例, $61.9 \%$ ) する症例が多くみられた。

3. 化学療法 2 クール施行例での 1 クール終了時まで のPNI の変動では, 全 2 クール終了時での化学療法有
効例では，上昇 $(6 / 10$ 例， $60.0 \%)$ ，無効例では下降 (6/9例， $66.7 \%)$ する症例が多くみられた.

\section{引用 文 献}

1) 西平哲郎, 秋元 実, 他: 癌患者の栄盖と免疫 能. JJPEN 2(3)：257-263 1980.

2) 西平哲郎, 平山 克, 他：栄養状態と免疫能, 医学のあゆみ 120：396-402 1982.

3）小野寺時夫：癌の臨床 栄 養。日医会誌 $93(7)$ : 1337-1342 1985 .

4）小野寺時夫：抗癌療法と栄盖指標. 癌治療と宿 主 3(1)：25-33 1991.

5) Smythe, P.M., Schonland, M., et al.: Thymolymphatic deficiency and depression of cell mediated immunity in protein calorie malnutrition. Lancet 2: 939-944 1971.

6) Law, D.K., Dudrick, S.J., et al.: Immunocompetence of patients with protein calorie malnutrition. Ann Int Med 79: 545-550 1973.

7) 中井祐之, 斉藤純一: 肺癌化学療法時の栄峑学 的予後指数 (Prognostic Nutritional Index) の 意義. 癌と化学療法 18(3)：493-496 1991.

8) Daly, J.M., Dudrick, S. J., et al.: Evaluation of nutritional indices as prognostic indicators in the cancer patients. Cancer 43: 925-931 1979.

9) Hiratsuka, H., Imamura, M., et al.: Immunohistologic detection of lymphocyte subpopulations infiltrating in human oral cancer with special reference to its clinical significance. Cancer 53: 2456-2466 1984.

10) Noguchi, M., Kohama, N., et al.: Clinical significance of laminin deposition and $\mathrm{T}$ cell infiltration in oral cancer. Head Neck (in press).

11) Valdivieso, M., Frankmann, C., et al.: Longterm effects of intravenous hyperalimentation administered during intensive chemotherapy for small cell bronchogenic carcinoma. Cancer 59: 362-369 1987.

12）平山 克, 西平哲郎, 他：癌患者の栄養状態と 免疫能，食道癌を中心に. JJPEN 11：947-953 1989. 